\title{
Afternoon Moonlighting - It Was a Must. The Dynamics and Paradoxes of the Croatian Socialist and Post-Socialist Labor Market
}

\section{Tihana Rubić}

Faculty of Humanities and Social Sciences, University of Zagreb, Zagreb, Croatia

This paper discusses the elements of socialist and post-socialist (un)employment and informal economy. A growing economic crisis and a reduced participation in the formal labor market in the newly-formed Croatian state in the early 1990s brought about an increase in unemployment and gave rise to informal economy. However, informal economy had been widespread even before, in the late socialist period in the former Yugoslavia, which was the so-called "golden age" of formal employment. Being formally employed generally did not discourage people from additionally engaging in informal economy.

This paper offers an analysis of the cultural and social logic behind informal practices, based on a qualitative research that was conducted in an urban settlement in the periphery of Zagreb among former full-time industrial workers, who are officially unemployed today, and who have been active in the underground economy up to the present day.

Key words:

Croatia, socialism, post-socialism, informal economy, family relations

\section{INTRODUCTION}

In the Socialist Federative Republic of Yugoslavia (SFRY) the problem of unemployment was present but hidden in a variety of ways (Cifrić et 
al. 1990: 166; Woodward 1995), often creating the perception that the notion of socialist unemployment was an oxymoron (Woodward 1995). However, unemployment in the socialist period was negligible in relation to its increase since the beginning of the transition process in the SFRY successor states.

Since the early 1990s, following the breakup of the SFRY, seven of today's nation-states achieved national independence and began to change their political and economic structure from socialism to a democracy and from a socialist economy to a capitalist economy. This was only the beginning of a series of lengthy processes, many of which are still underway. Long-term stagnation of employment in the Republic of Croatia and a continuous rise of the unemployment rate (Ott 2002: 3) were characteristic of the period of the economic and political transition - "a demanding transformation of the post-socialist society” (Šundalić 2001: 65). The 1990s saw an “'explosion' in the number of the unemployed" (Galić 2008: 1). "Massive liquidations and bankruptcy proceedings" (Kerovec 2001: 271) led to some 500,000 workers losing their jobs. In a single year, from the end of 1990 to the end of 1991, around 100,000 new unemployed were registered by the Croatian Employment Service (CES). In 1994 Croatia's unemployment rate was 18\%, the highest among transition countries (Vojnić 1996: 187). From 1991 to 1995 the situation in the formal labor market worsened with the onset of the war. Although the problem of high unemployment accompanied the transition process in other post-communist countries as well, Croatia's unemployment rate was extremely high in comparison (Teodorović 2001: 141). The peak unemployment rate at the national level, as a result of the turmoil in the 1990s, was reached in late 2001, with as many as 395,141 of registered unemployed, i.e. nearly $10 \%$ of the total population. ${ }^{1}$ Not surprisingly, therefore, the staff of the CES and of related institutions (e.g. the Centre for Social Welfare) in the City of Zagreb described the increase in unemployment during the period as a "river" of unemployed. Given that the City of Zagreb has been accounting for about $10 \%$ of total unemployment since 1990, the increase in the unemployment rate on the national level brought about a proportional increase in the unemployment in the capital city (there were 17,745 unemployed registered in Zagreb in 1990, and 41,181 unemployed registered in the late 1990s). ${ }^{2}$

${ }^{1}$ Source: Croatian Employment Service, Zagreb. At http://www.hzz.hr/ (accessed 1 October 2011)

${ }^{2}$ Source: Croatian Employment Service, Zagreb. At http://www.hzz.hr/default.aspx?id=7567 


\section{METHODOLOGY}

My research focuses on the qualitative features of both employment and unemployment, and it points to the continuous importance of informal economy.

The growing economic crisis and the rise in unemployment gave rise to formal activities in the gray economy starting with the mid 1990s, soon after socialism was abandoned and the independent state established. However, narrative sources and individual experience show that in the former Yugoslavia, during socialism, the "golden age" of formal employment, informal economy was also widespread, and that being formally employed did not discourage people from engaging in informal economy. This is one of the dynamics and the paradoxes of the socialist labor market indicated in the paper's title.

The following sections will look into and discuss the elements of socialist and post-socialist (un)employment and informal economy, concentrating mostly on socio-cultural dimensions of the phenomena (cf. Ott 2002). The analysis and conclusions will be mainly based on narrative sources ${ }^{3}$ and information gathered during ethnographic research conducted in several stages in one of Zagreb's neighborhoods during a period of three years, starting from 2007. In order to protect the informants, the part of Zagreb in question will not be named, and the informants will be referred to by pseudonyms rather than their names. Certain characteristics of the settlement where the research has been conducted, which are essential for the contextualization of the research (e.g. the necessary contextual/ historical information), will be presented. However, since there are several settlements with similar characteristics around the greater Zagreb area, the description will not lead to the disclosure of the settlement in question.

I observed the development of the settlement, social relations within it, and the life of its unemployed residents diachronically, looking into the period of socialism (when the settlement started to get its today's character and social structure), and the post-socialist era (when many residents of the village, particularly second-generation immigrants, experienced the collapse of the industrial sector during the 1990s by losing their jobs). My research is thus mainly based on the principle of territoriality: the

\footnotetext{
(accessed 30 March 2011)

${ }^{3}$ Quotes from interviews are referred to using pseudonyms and the date of the interview in the brackets (e.g. Mirko, 30 January 2009).
} 
settlement where my informants have been living and "surviving". As such it forms a micro level of their everyday lives and a shared experience of unemployment, as it is a specific spatial framework in which these individuals live, work and communicate with each other for their own daily needs etc. In ethnological and cultural anthropological research this micro framework does not merely refer to the physical coordinates outlining the research area, but also refers to a required sociocultural contextualization of the research topic. However, the chosen spatial and social framework does not exist in a vacuum, but as part of broader social, economic, social and political processes (the macro level), so the described territorial framework (a single settlement) that I set for the study should be seen as loose. Thus my research often spread beyond these limits, not least because the daily activities of my informants did not take place only within the settlement. Instead, they used the existing social and other infrastructure on the level of the whole City of Zagreb; which meant that the whole city naturally became the "stage" and the locus of the research.

Apart from the principle of territoriality (locating research in one part of the city), the second principle was the "snow-ball" method in finding informants, as a relatively "spontaneous" way of discovering the mechanisms and logic of acquaintanceship and other social relations among the unemployed. Thus I did not investigate, nor did I intend to investigate, all the unemployed in the settlement (the young, the middle-aged etc.), but a selected focus group of unemployed with specific generational and socioeconomic characteristics. My interlocutors were men and women, more than 50 of them, permanently living in the settlement, aged between 50 and 65 at the time of the research, who were not formally employed at the time, and were mostly forcibly pushed out of the formal labor market when they were in their forties, after the collapse of socialism. So they have not "always" been unemployed, but are people who have had both the experience of formal employment (in socialism) and unemployment (in post-socialism) from their twenties or thirties until their sixties.

${ }^{4}$ I deliberately use the term "survival" in quotation marks, because I conceive of it mainly as a metaphor. It is a common discursive element in all narratives. Specifically, there is a wide range of economic and other conditions that people are in that they describe as precarious and using the term "survival". However, I will not deal with this phenomenon in this paper. 


\section{LITERATURE REVIEW}

When Ott says "[d]ifferent evaluation methods give different results" (2002: 1 ), this is above all a scientific attempt to comment on the quantitative and statistical reports on informal economy. Estimates vary from $15 \%$ to $37 \%$ of the Croatian gross domestic product (GDP) depending on the survey, with slight annual increases and decreases (Bičanić and Ott 1997, Ott 2002: 2). In a word, it is estimated that "nearly every other unemployed person works in the informal economy earning a certain income, in order to survive and to be able to start a permanent legal business" (Malenica 2007: 132).

The term "informal economy" refers to a set of activities that are not part of the registered, formal labor market. According to the legislation of the Republic of Croatia, "any person who receives an income" is subject to income tax and registration of income. Failure to do so (for example, various private, unregistered money transactions) are considered to be part of the informal economy, and in this sense they are illegal. In the literature this is referred to as the parallel system, which usually means a business that does not operate within the law and the formal labor market. This is termed differently by different authors, e.g. as "gray" economy, parallel economy, informal work, informal employment, informal employment, underground economy, shadow economy or hidden economy.

According to the anthropologist William Haviland, informal economy is "a network of producing and circulating marketable commodities and services that for various reasons escape listing (enumeration), regulation, or other types of public monitoring or auditing. Such enterprises may encompass nearly all agricultural products [...] repair or construction work, begging, street peddling, performing ritual services, money lending [...]" (2004: 198). It exists among the poorest (Hart 1973) and among elite groups (cf. Sampson 2002: 46), but also shapes, and to a great extent, ordinary people's everyday life.

Narrative sources from this research prove that informal activities are nothing new and are readily available to everyone. Moreover, for many it is sometimes difficult to imagine that some tasks can be accomplished outside of the "informal" sector (jobs such as cleaning, baby-sitting, elderly care, construction, repair, selling fruits and vegetables at the market, etc.). Although these practices are "well-known", they are under-researched, especially by implementing qualitative research methods. Therefore, a lot 
of qualitative research still needs to be done in the future, even though the topic has been inaugurated in the social sciences and humanities in general in the early 1970s, with the famous and influential research on the informal sector in African Ghana performed by the British anthropologist Keith Hart (1973).

Although there are no targeted and longitudinal studies, Croatian ethnology did indirectly record data about daily work and economic life that took place in the "informal" sphere, even in the pre-socialist period. For example, there are data on certain "hidden" levels of zadruga, ${ }^{5}$ i.e. of individual nuclear families within these families/households in the last decades of the 20th century (Černelić 2006; cf. Černelić and Rubić, forthcoming), at the time of zadrugas' formal dissolution (Pavličević 1989: 210). The dissolution was largely a result of the law in force at the time, tax and policy regulations and restrictions which were not convenient for zadrugas (ibid.; Kaser 2012: 397). The "hidden" levels included, e.g., the practice of a "secret" dissolution of the zadruga which nuclear families practiced in order to circumvent the law and thus avoid expensive legal and registration costs (Rubić and Birt 2009). The "secrecy" of the dissolution was directed toward the authorities, whereas the local community and the family members knew exactly when, how and among whom agreement was reached. It meant slipping through the cracks of the legal system and was the result of specific individual and family interests that formed their economic rationalization (Rubić and Birt 2009; cf. Černelić and Rubić, forthcoming).

Ethnographic literature provides more data on "informal institutions" and activities outside the formal labor market and formal regulations in the 20th century. These are, for example, "double standards" regarding doing business within a voluntary cooperative vineyard (Supek 1989), theft as part of the everyday functioning of zadrugas (Rihtman-Auguštin 1984), alternative forms of trade and economic activity on the individual and the family level (Muraj 1990; Muraj 2002; Šantek 2000), the unwritten, traditional strongholds of sales at fairs (Rubić 2008) and begging (Mucko 2010).

Informal economy is outside the law, and its basic principle is tax evasion and a circumvention of the established formal and regulated systems. However, it has a strong social legitimacy (Štulhofer 2000) and is generally

${ }^{5}$ Several families living in a rural area with some common property and strictly hierarchically structured labor relations. 
socially approved as one's survival strategy and/or a strategy of resistance.

This concept largely fits into the frame that is generally referred to in ethnological literature as "common law" (Rihtman-Auguštin 1984: 52; Čulinović-Konstantinović 1984), which, according to some legal concepts reported by Čulinović-Konstantinović, refers to unwritten norms, to a "series of [...] unwritten legal regulations that were in general long-term use" voluntarily accepted "suitable for a particular community [...] and sanctioned by the State" (Čulinović-Konstantinović 1984: 52). This is not at odds with the characteristics and the functioning of informal economy that Rihtman-Auguštin found in her 1980s research on zadrugas.

Writing in 1996 about the 1980s, Dunja Rihtman-Auguštin, following the contemporary trend of studying the attitudes of individuals to the government and the law (the State) in Mediterranean societies, found that there was a widespread polarization in Croatia between what was considered legitimate and what was considered legal as well as a prevalent distrust of the State by the "ordinary" people: "The lack of confidence in the government is primarily due to the ambiguity between legality and legitimacy, which are in conflict. [...] This refers to the rule of law (legality) vs. a dominant notion of justice (legitimacy)" (Rihtman-Auguštin 1996: $60)$. In the words of an informant:

We [her close kin members] have to get along and help each other out. What else are we supposed to do, who else would help us otherwise? Do you believe that politicians would?! (Ljiljana, 14 June 2010)

However, activity in the sphere of the informal economy among my interlocutors was presentbefore the 1990s as well. Themostrelevantaspects of everyday life, such as housing and employment of close kin members, were handled through "informal" strategies, regardless of one's formal employment. In relation to that, collective values built up under socialism and before, such as economic security throughout formal employment, show a significant gap between the narrative and the experiential level. Narrative sources suggest that, in practice, the lack of money was largely resolved informally, outside of the formal labor market. Informal economy was a model and a strategy to cope with the lack of money, which was the result of low wages earned in formal employment. In their narrations, my informants uniformly mention job safety in socialism. Job safety refers to several aspects: regular salary, long service in a single job, the fact that many people were allocated housing by the company where they worked 
and that workers' could spend their holidays in resorts. However, the lack of money and insufficient income from formal employment to fulfill all of one's needs (even when there were two incomes i.e. two "breadwinners") was the greatest motivation to become additionally involved in the informal labor market.

One wage, my husband's, covered all the usual overheads and bills. My wage was spent on food. So, you see, what would we have done without my moonlighting? (Kata, 10 June 2008)

Thus, although the socialist ideology worshiped workers, in practice they were largely left to their own devices and had to fulfill their needs in the "hidden" spheres and through informal mechanisms. Stories of workers who worked in factories in the morning and took a job moonlighting in the afternoon (even in the factory where they worked but "for their own needs") were common and frequent. When one worked "for one's own needs" this meant that the material came from the factory, but was informally sold outside the factory and the profit went directly to the worker. This was not considered as theft, but a "normal" way of supplementing one's income. Thus, many people report that houses were not built by spending regular salaries and employing registered workers, but with the help of family members and by using money earned while "moonlighting". Formal and informal spheres of labor did not only exist in parallel, but complemented each other and were intertwined, and therefore removing materials from one's formal job and taking them to one's garage was ubiquitous and also socially legitimized:

If I could only keep count of the times that I took something, no matter what! You put one tool in your pocket: a screwdriver, a wire, any tool... When I saw the others doing it, I did it too. My garage was full of stuff from my formal job; so much stuff has accumulated in my garage. (Ivica, 14 October 2009)

There is no doubt that, in the long run, the practice of supporting fraud and outsmarting the system (i.e. taking raw materials from the formal sector where one was employed) has an adverse effect, because it means "cutting the branch you are sitting on". However, this is completely irrelevant in the narratives of my informants. The individual "sense of responsibility" for the consequences of tax evasion (the impact of informal economy on the national budget) was not at all cause for the individual to stop participating 
in the informal economy. This extends to the present day (cf. Štulhofer 2000).

Furthermore, given that nepotism was a universal hiring principle, and did not only apply to certain high-ranking positions, the formal employment was also inextricably connected with various informal levels. The data are extremely relevant for the analysis of both the persistent and newly appearing qualitative features of employment and unemployment, informal economy and social relations, both in socialism and today.

Literature on the transition process in Croatia often mentions that the "old" values were very quickly replaced by new values of the postcommunist transition and the new labor market (Cazes and Nesporova 2003), such as flexibility. This happened as if people began to live by the new model "overnight". If one takes into consideration that people who were formerly employed once had been permanently engaged outside the regular working hours in an "extra" job "moonlighting", this change in practice no longer seems so pronounced. In a word, associating "flexibility" exclusively with the post-socialist labor market is erroneous, and might be caused by the fact that labor-market flexibility was promoted as an essential feature of the new, market-oriented economy during transition (cf. Dunn 2004), in opposition to the "inflexible" socialist system. However, taking into account the widespread practice of "ordinary" people participating in both the formal and informal economic sphere during socialism, it can be claimed that there was an unintended flexibility present on the practical level of the former socialist labor market.

Although it is often pointed out that under socialism "flexible forms of employment were exceptional and limited to certain categories of workers (e.g. managers, academics and a handful of other highly qualified professions and seasonal workers in agriculture and food industry)" (ibid.: 43), if we take into consideration that formal employees participated in the sphere of informal economy, it is reasonable to claim that this was a type of "labor flexibility" - "working several jobs", as one informant explained: Afternoon moonlighting - it was a must (Marko, 27 October 2010). Doing formal work in the morning was often accompanied by working informally in the afternoon i.e. "moonlighting". It was common by all accounts. This is by no means a statement in support of the model, but is just meant to draw attention to the fact that the ubiquity of working in the informal sector was not a feature that came about after socialism, as claimed in the literature and suggested by public perception and discourse, but had also been present earlier, during socialism. Only qualitative information which refers to both 
spheres - the formal and informal labor markets, socialism and the postsocialist period - can reveal these "hidden" features of the labor market as a whole, its dynamics and contradictions. In practice, if not in intention, socialism was a "flexible" system. It was also propulsive at different levels, as confirmed by a number of direct individual experiences, even though this is the last thing that comes to mind in relation to socialism on the level of public perception. It was propulsive because vitally important issues such as employment and housing were solved through negotiations with the representatives of various institutions, such as the (local) authorities, i.e. by informal means (bribery and exchanging favors).

Everyone knew [the inspector's name]. He was a construction inspector and, as you know, all of us built our houses here illegally. Now, you know how this was done. A sausage here, a lamb and some brandy there, threatening a little or buying someone off. I would go to the City and leave him the money there, discreetly. And this is how I managed to build my house. He never tore it down or told on [in the sense of reporting 'moonlighting' practices] those who helped me and worked on building my house. (Željko, 23 October 2010)

\section{INFORMAL ECONOMY AS A SYMBOLIC RESOURCE}

There are a number of qualitative aspects of the informal economy that are presented and analyzed here. One of the most prominent is that people generally speak very openly about their own participation and the participation of others in the sphere of informal economy, and that they normally legitimize their practices using statements like: "I get by" (Marko, 3 November 2010), "It is better to do this than to sit at home" (Ružica, 4 October 2009), "Everyone's doing it" (Ante, 17 June 2009), "What else can I do?" (Sanja, 7 November 2010), "You have to do it in order to 'survive"” (Kata, 21 May 2008).

Participants and non-participants interpret and present the activities in the field of informal economy primarily through the economic paradigm of "necessity" which is a result of a lack of job offers on the formal labor market. We have already indicated that participation in the informal labor market was generally motivated and rationalized by referring to economic 
(financial) reasons. However, informal work does not follow a purely economic logic, nor is it only related to the insufficient supply of jobs in the formal labor market nor indeed to earning insufficient salaries from formal work (during socialism). There is a scale of implicit motivations as well as of a certain "habituation". There is a widespread "collective rationalization" (Macura 2005: 8) or "social legitimization" (Štulhofer 2000) of the informal economy. Legitimization of these activities is a pattern, although people are aware of the illegality of these practices: those who participate in the sphere of the informal economy are neither uninformed nor misinformed. Being aware of the fact that these activities are not legal can be seen in how they are talked about, by regularly using diminutives and expressions whose aim is to trivialize the profit made from these activities: "There is a small, tiny profit from this job" (Željko, 23 October 2010), "Yes, from time to time you earn a little" (Kata, 21 May 2008), "You make some smaller amounts" (Ljiljana, 14 June 2008).

In addition to being collectively legitimized, informal economy is the way for an individual to build and strengthen his/her symbolic and social capital (status): the informal economy network is a symbolic resource. Unrecorded economic transactions are motivated by different reasons. In addition to the logic of saving and/or earning, there is the logic of resistance to formal (state) institutions and centers of authority and power, as well as the symbolic logic of creating, supporting and/or perpetuating the concepts of "acquaintanceship" and of "useful acquaintances" as a social value.

I know a good plumber. I'll give you his number, just mention me, I think he'll lower the price a bit. (Drago, 4 November 2009)

I have a lady at the open market who knows me, so I always get a bit more from her, or the chance to choose better vegetables. (Ivka, 6 November 2009)

It is important to have "a lady who knows you", a plumber or a car mechanic, both in the economic and in the symbolic sense. Examining and evaluating the validity of one's choice (of "one's own" plumber, car mechanic, etc.) is beside the point. What seems to be crucial, regardless of the validity criterion, is whether the individual feels that s/he benefited from the acquaintanceship in a way that would be impossible without it. For example, one can get cheaper prices for some services, a better selection of fruits and 
vegetables, a more committed and faster car mechanic, one is less likely to be hoaxed by the seller, etc. It is also important to the individual to verbally mediate the information that he/she has "his/her own" seller, which is a type of symbolic proof and of self-affirmation.

Activities in the sphere of informal economy can also be based on the logic of exchange and reciprocity of services, without direct money transfers. For example, one day an unemployed man repaired a person's bike, and in return got a cubic meter of sand which was left over from the construction of the other person's house. The fact that the sand was obtained "for free" is perceived as positive by others in the neighborhood, and the person who got it is seen as "someone who manages to get by". Although I had not heard this directly, I witnessed many casual conversational situations "over the backyard fence" in the neighborhood where the case of the cubic meter of sand was an "important" issue over the next three days; there was an open debate on this successful transaction and the person who got the sand was evaluated "as someone who is well-connected". There was another thing that this person tried to convey to the others, in order to justify the fact that he suddenly had a pile of sand in the middle of his yard, which might invite a question from someone in the neighborhood: How is it that this person, who is unemployed, suddenly has the money to buy building materials? Once it was conveyed that he "earned" the sand from one of his neighbors, it would be perceived as "appropriate" and in balance with his limited financial resources, which is in line with a socially "acceptable" and expected economic behavior of an unemployed individual. A number of "services" such as this can be done through a useful "acquaintance". Money in the physical sense is not used as a means of compensation. Rather, people strive for reciprocity (which is crucial in maintaining family and other social relations), and it is treated as a "means of payment". That is to say, one returns in kind the equivalent of the service rendered. Achieving this reciprocity raises the social capital of the individual. Correspondingly, "capable" individuals, who are good at arranging transactions that are not based on direct money transfer but the exchange of goods and services, are highly regarded. Moreover, the interviewees regularly mentioned known individuals from their immediate surrounding (street, part of the town) by name; these were individuals who they knew had these special "skills" or a "gift" to earn a living and get by in the sphere of informal economy, to circumvent the law, to negotiate with the local authorities to their advantage, to agree on a quid pro quo arrangement and the like: "I do not 
know how to get by in that way. You have to know it, or have 'the power of speech'".

Moreover, one of the perceptions of one's participation in these activities is that of "ensuring social justice".

Just like things were being talked about and done at one point in time, they are still done today: you take from where things are in abundance and put them where there are none! (Ivica, 13 January 2010)

This is the basis of persistence and ubiquity (Šakić 1999) of these activities in the sphere of informal economy. One part of this is narrating on the observed characteristics of these activities: when individuals talk about their own activities, which were actually a way of defrauding companies where they worked, they are regularly presented as part of first-hand and "good" memories of the period when they worked for the company.

In general, "moonlighting" was a common basis which allowed better functioning of different levels of social and economic family life. It was a common strategy to cope with financial difficulties and shortages. However, it was more than that. In addition to its economic relevance (in terms of satisfying the needs of the household budget that could not be met by salary from formal employment) it also had a symbolic significance. It was an expression of symbolic resistance to the centers and institutions of power (a "strategy of resistance").

\section{THE IMPORTANCE OF FAMILY NETWORKS IN INFORMAL ECONOMY PRACTICES}

In socialism the informal economy was an extremely important "survival strategy": "This is how we built our houses" (Ivka, 6 November 2009). Low-wage workers regularly worked various parallel "additional jobs". It was something "we all do". The workers' wages were small and one could go on holiday with the family only if one spent what s/he could earn "moonlighting" during the year, because one could earn less working in the company than "moonlighting".

As the processes of deruralization, urbanization and industrialization advanced after the Second World War, the socialist state was interested in 
ensuring and supporting the project of collective housing in cities, as part of the social or economic policy and ideology in which housing was seen as a "basic requirement for the reproduction of the labor force" (Seferagic 1988: 43). This was referred to as social housing, and it meant that the state took care of the housing issue (ibid.: 44). Workers with a housing issue were shortlisted in their companies, and were given the tenancy of an apartment. In the early 1960s, a housing fund was established, and 3\% of each worker's net salary went towards the fund. Although all workers were required to contribute to the fund, only a small portion of them felt the benefit of it (cf. Radonjić 2001: 389). The difference was primarily evident in the industrial sector, with the oil and gas industry leading in the number of apartments available for workers, and the textile industry providing about one apartment per 3000 workers. ${ }^{6}$ This difference was also expressed on the level of public discourse. People would say: "Moj dinar, tvoj stan" (My money, your apartment; Zlatko, 14 October 2011).7

By the end of the 1960s there were around 460,000 workers formally employed in Zagreb (Hutinec 1971: 23). For this "army" of workers, mostly immigrants, ${ }^{8}$ housing shortages were acute. Thus, for example, the annual housing deficit in 1971 was estimated at 36,800 units (ibid.: 21), and a little earlier, from the late 1950s to the mid-1960s annually "eight apartments [were built] per 1000 workers" (Blažina 1965: 398). As many have said, it was an "urbanization without adequate infrastructure" (Sekelj 1990: 1415), and the "economic growth [...] was not accompanied by an adequate growth of housing construction, due to an underdeveloped (sic) system and the absence of a housing policy" (Hutinec 1971: 21).

One group of workers worked in the cities, migrating to cities daily (working as unskilled or semi-skilled workers). They still lived in rural areas, which is in line with the fact that the majority of residents who left agriculture, found a job in the immediate vicinity of their residence or within their region (Puljiz 1977: 102). However, the largest number of

${ }^{6}$ It is from the interview with one of the employees at the former Bureau for Urban Planning and Development of the City of Zagreb (Zavod za izgradnju Grada Zagreba), 25 November 2011.

${ }^{7}$ For instance, we learn from detailed statistical reports, such as the Yugoslavian statistical report publication entitled Jugoslavija 1945 - 1985: statistički prikaz, published by the Federal Bureau of Statistics, which contains data referring to a variety of social and economic categories in the forty-year period) that in 1983, out of the total number of employees in the public sector, only every seventh worker applied for an apartment, and every twelfth for a house loan.

${ }^{8}$ Starting with the 1960s, the largest part of people who were looking for a formal job in the growing industrial sector in Yugoslavia were immigrants of peasant origin, unskilled and semiskilled workers (Puljiz 1977: 107). 
workers resolved the housing issue by permanently immigrating to the city and building an illegal house on the city's outskirts. And in socialism, building a house was a continuous occupation which involved a huge range of informal activities - including the purchase of construction material, undocumented workers to build the house, building a house without a license, or bribing and outsmarting local supervisory agencies and the local authorities.

The settlement built in this way has never been part of any urbanistic plan, as was the case with a working-class neighborhood that had been built specifically to address the housing needs of workers (cf. Kremenšek 1970), nor was it part of ambitious postwar urban projects such as the ones in the southern part of Zagreb (cf. Gulin Zrnić 2009). The settlement developed based on the principle of the individual, through private and illegal house construction (small family houses). Unlike the urban planned developments in the southern part of the city which consisted of neighborhoods and apartment buildings planned and designed in accordance with the local internationally recognized standards of urban planning, most of the eastern and western outskirts of Zagreb, including the settlement where the research was conducted, were built in an informal way, partly because there were shortages in the formal housing sector, even when it was undergoing its greatest expansion.

Private ownership under socialism is generally still an insufficiently explored topic. The first thing that comes to mind in relation to socialism is the concept of housing and "tenancy rights" rather than private property, although both qualitative and quantitative indicators show that they had an equal share. ${ }^{9}$ Figures relating to the construction of private and residential housing show, for instance, that from 1952 to 1961 the number of private houses increased tenfold..$^{10}$ According to the public perception (which is of course exaggerated, but it is illustrative) the greatest part of today's Zagreb was built in this way from the 1960s until today; that is it was built illegally, based on individual building initiatives and informal helping networks. Most of the private houses built in the neighborhood where I conducted

${ }^{9}$ Statistical data from the Yugoslavian Statistical Review Jugoslavija 1945 - 1964.: statistički pregled, published in 1965, p. 164.; and from the interview with one of the employees at the former Bureau for Urban Planning and Development of the City of Zagreb (Zavod za izgradnju Grada Zagreba), 25 November 2011.

${ }^{10}$ Statistical data from the Yugoslavian Statistical Review: Jugoslavija 1945 - 1964.: statistički pregled, published in 1965, p. 164. 
my research still remain illegal today, except for those buildings that had been built before 15 February 1968, which were legalized by a political decision that took effect immediately and was applied automatically, ${ }^{11}$ as an attempt to resolve the large number of existing houses that were illegal, which were a result of the huge influx of migration to cities (cf. Puljiz 1977: 104-105).

It [the settlement] was built gradually. One house here, then others came, then they started building a house there, a basement, then room by room, little by little. The settlement was built like this and all the houses here. Look at it now, it looks like a village and not a city... (Kata, 2 November 2009)

Therefore, the construction of single-family houses, which ran in parallel to being formally employed during the socialist period and in parallel to the huge urban developments at the time, is an interesting phenomenon in the historical development of the City of Zagreb and many other Croatian cities. My interlocutors, who are unemployed today, have taken part in the construction of their houses over the years, some of them ever since their childhood, when their parents entered the expanding socialist labor market and started building a house. For many, building a house is a decades-old, multigenerational family "project", as well as an example of exceptional family and individual assistance which one can get "for free", and which is unrecognized by the law.

Although it was largely the first generation of immigrants that "carried the main weight" of construction, because the basic elements of the house were built by them, house building, repairs etc. continue to the present day and are a never-ending project.

One day you build a fence, another day you put it up, yet another you do something else... There is a lifetime of work on a house. There's truth in saying - a house is a "bottomless pit". (Ivka, 6 November 2009)

Let us indicate one other thing, also closely related to family assistance and support. Family help, assistance and solidarity, expressed mainly by

11 This was done based on the Basic Act on Building Investment Facilities (Osnovni zakon o izgradnji investicionih objekata). However, cadastral survey conducted in 1963 (it was the first postwar cadastral survey and the first contemporary one) did not include land registry data, so the issue of ownership of buildings in part remained legally unregulated. 
providing one's work and services "for free" (especially helping the youth), is seen as a value in itself, it forms a pattern and is an imperative in social relations (Janković, Berc and Blažeka 2004; Rubić and Petrak 2010; Rubić and Leutloff-Grandits, forthcoming). On the individual and the family level, all this significantly influences the perception and experience of one's (own) unemployment. My research also indicates that the importance of a family, as an informal "institution of care", is strongly confirmed on all levels of everyday life, both in the periods of crisis (e.g. during the war and immediately after the war) and in the recent context of being unemployed. Daily assistance (child care, elderly care, construction work, transport etc.) is limited mainly to closer relatives and first neighbors, takes place mostly in a vertical line, between generations, and is usually not reciprocal, with much more assistance provided by the older generation to the youth, and much less vice versa. It has been confirmed that "if an older person needs help, it will be provided by their immediate family" (Podgorelec and Klempić 2007: 111). However, help provided by the younger generation to their elderly is less frequent than vice versa. In times of crises there are a growing number of needy family members, but there are also more sources of aid (helpers). Solidarity spreads to members of the extended family, to a broader network of relatives and/or a larger number of neighbors and/or friends. However, assistance in times of crisis has a (limited) duration - when things stabilize, assistance ends. In this regard the already mentioned issue of illegal house building is a good example, since it reflects a set of positively valued social relationships (cooperation, interaction and solidarity).

"In the social life of an individual there is an overlapping of those relationships that have practical significance" (Augustins 2010: 333). The mentioned issue of illegal house construction is very interesting not only because private property in socialism is ethnologically under-researched or because house building reflects a clash between legal regulation and "real" life, but also because it reflects a set of positively valued social relationships (cooperation, interaction and solidarity), especially among family and kin members. Thus, constructing a single house might regularly easily involve some twenty people, mostly relatives. 


\section{CONTINUITY BETWEEN SOCIALIST AND POST-SOCIALIST INFORMAL ECONOMY PRACTICES}

Post-socialism and transitional changes in Croatia started in the late 1980s and early 1990s. This was a time when the socialist political and economic system was abandoned and the Croatian independent state was formed. There weresimilarities in the transition process in former socialist countries, but the process was by no means the same everywhere. As was the case in the other European former state socialist countries, Croatian transitional, post-socialist experience also brought about the creation of new political and economic elites, which caused a widespread public perception of a fundamental illegitimacy of the transition processes (Guardiancich 2007; Malenica 2007; Šakić 1999; Županov 1996). Still, it should be noted that the transition period was fundamentally marked by war (from 1991 to 1995) and its consequences (Guardiancich 2007: 92-94; Malenica 2007: 115). Many workers who used to work for former large state-owned companies and lost their jobs in the transition period, definitely found compensation in the sphere of informal economy (cf. Karajić 2002: 277, 283-284). Still, informal economy was not unknown to them; it is more likely that most of them (especially men) just went ahead with their previous informal businesses, including "moonlighting", or that they merely redefined them. On the other hand, there are those who switched from their earlier source of income to a new one. In the "grey" zone of informal economy skills and strategies of bypassing the law are more relevant than goods and services one can provide, i.e. it is irrelevant if one's way to earn money is currently related to a pair of shoes, a pair of sausages, cosmetic services or selling cars. I will illustrate this dynamics, flexibility and diversity of goods and jobs, on an example. A worker who had worked in the quality assurance department (Odjel za škartiranje) of a now non-existent shoe factory had been secretly writing off pairs of non-defective shoes as defective for years, so as to be able to buy them at "bargain" prices "for her own needs". Later, when she was formally unemployed, she joined with a partner and participated in the informal resale of used cars and various other items at the Zagreb trade fair and a Sunday fair. They bought auto parts from authorized supplier but at a discount (30-50\%), and this was recorded in the retailer's business books as having been sold to the employees "for their own needs". To return the favor, my informant used to send new customers to the "generous" merchant. 
Moreover, while her partner is usually engaged in marketplace conversations with potential customers interested in buying a car, she sells a variety of useful objects and used auto parts at the Fairground. She goes to the Fairground once a week, and earns around 500 kunas.

Current social sciences and humanities research rejects the concept of an isolated and autonomous nuclear family (Heady and Schweitzer 2010; Lee 1980; Segalen 1984; cf. Milić 2007: 107-108). In practice, a truly independent nuclear family is always more of a tendency than a "reality": among other things, during my research I came upon many stories about a young nuclear family that, when both spouses lost their jobs, would have had an empty fridge if it had not been for their parents to fill it. Today, these retirees are a large and important resource of direct financial and emotional support to their adult (long-term) unemployed children (cf. Leutloff-Grandits, Birt and Rubić 2012: 595).

One elderly person explained her motivation to earn extra money in her old age, in addition to her regular pension:

I have to help my son. He has a job, but his wife doesn't. Am I just supposed to sit and wait for her pay that doesn't arrive? In this way I am helping them as much as I can. (Kata, 30 August 2010)

An elderly man helped the younger generation by giving them a large amount of money, when he finally got his severance pay after many years of waiting:

When my severance pay arrived I gave some of it to the young ones so that they could build an upstairs flat and the roof frame for themselves. My son, the younger one, lives upstairs. I also had the tombstone at the cemetery restored. So now they [his son and daughter] can rest assured that it's been sorted. And I still have some money left in my savings account for a rainy day. I help the young ones, what can I do? It's a good thing I can afford to help them. Even though they work, it's not enough, because their salary is low and irregular, a trifle. Only think how those who can't afford to help their own children feel? (Željko, 4 June 2010)

I will mention one other example. One of my informants, who was born in 1945 and got her first job in 1965 (at a nearby food factory), was let go in 1997, only a few years before her full retirement age. But, she still got a very good pension, because she had put in many years of service in the 
company. Here is what she says:

It was around 4000 kunas, my pension. Can you imagine? I am very happy because of that, because today women who do these difficult jobs in the production area, as I did, they are lucky if they get a pension of 2200 kunas, with the same length of service! So their pensions are more like 1600 kunas now. Because they used to calculate the pension based on your average income, and at that time we had a great average, 1300 German marks, and we got a bonus every three months, overtime, a good sign. (Anka, 4 October 2009)

This woman regularly gives money to two nuclear families - the family of her unemployed daughter and her unemployed son.

Another informant explained that when he was finally paid his severance pay, it was not even a "small" amount - it was around 15,000 euro. He then went into early retirement, as he had not reached full retirement age.

But what happened to the money? You give one granddaughter some for this, you give some to the other, my son needs this and that... Soon it was all gone, and I did not even feel it. (Kata, 12 January 2009)

Today, retirees such as the ones mentioned above are a large and important source of direct financial and emotional support to their adult (long-term) unemployed children. Moreover, the unemployed rely on various forms of transactions and help from the family and within the family, and they rely on economic and social interactions with relatives and friends who still live in rural areas (their place of origin). One of the most important motives and drivers of these relationships is one's parental house or land. It is both a physical and a symbolic gathering place for dislocated families. Today, economic and social interactions between family members from villages and those from the city are so ubiquitous among my informants, that I perceive them as some of the key elements in enduring one's unemployment hardship. Many of the long-term unemployed own a family house or land in rural areas (in their place of origin) and they go there for the weekend. Often, if there are more heirs in a family, one of them still lives there.

These weekend visits are an opportunity to strengthen kinship ties through working together in the house, on the house, or around the house (e.g. renovation, mowing, harvesting, butchering, planting, etc.). Working together on the house and around the house, which follows the principle of 
reciprocity and thus contributes to alleviating potential conflicts within the family/kinship, actually empowers the community. On their return from the village, people always bring bags full of home-grown food (such as milk, honey, eggs, cheese, meat and meat products, fruits and vegetables). For them this has a dual significance: a symbolic value (a statement of "care") and immediate economic importance. Those who have relatives in the countryside with whom they maintain such contacts have more "healthier" food throughout the year. Many of my informants told me: "We are never hungry; we have everything, because we often bring many things from the countryside" (Kata, 3 November 2009). Cost saved on food in this way is quite substantial. If one is additionally a user of the city's soup kitchens (and many are), the problem of daily food supply (if we ignore the aspect of stigmatization) is quite satisfactorily resolved.

\section{SUMMARY OF RESULTS}

This paper presents an analysis of the cultural and social logic behind informal practices on the basis of qualitative research that was conducted among former full-time industrial workers, who are officially unemployed today, and are active in the underground economy, in a settlement in the periphery of Zagreb.

Several ethnographic examples illustrate the importance of three key aspects (themes) of socialist and post-socialist (un)employment and labor markets: 1 . continuity between socialist and post-socialist informal economy practices; 2 . informal economy as a symbolic resource; 3 . the importance of family networks in informal economy practices.

Family support and participation of the unemployed in the sphere of informal economy proved to be a dominant "shock-absorber" of the hardship resulting from earning insufficient income in one's formal job. These are certainly not the only mechanisms through which the unemployed seek ways to alleviate the hardship of unemployment. Still, this study shows that they are the cornerstone of the "survival" of people who used to be employed in socialism and became unemployed in post-socialism. Finally, informal economy is a persistent, continuous and widespread phenomenon in socialism and the post-socialist era.

In this paper, (un)employment was considered within the context of two periods (systems): socialism and post-socialism. My research process 
is thus partly historical-reconstructive (considering the present based on past knowledge), as well as reversible (based on the critical analysis of the transition, one can largely rethink and rediscover far less visible experiences from the socialist past).

\section{REFERENCES AND SOURCES}

Augustins, Georges. 2010. "Kinship, neighbourhood and community in perspective". In Family, Kinship and State in Contemporary Europe. Perspectives on Theory and Policy, Vol. 3, Patrick Heady and Martin Kohli, eds. Frankfurt and New York: Campus Verlag, 331-346.

Bičanić, Ivo and Katarina Ott. 1997. "Neslužbeno gospodarstvo u Hrvatskoj - uzroci, veličina i posljedice". Financijska teorija i praksa 21: 1-30.

Blažina, Zdravko, ed. 1965. Zagreb: jučer, danas, sutra. Vols. 1-2. Zagreb: Epoha - Matica Hrvatska.

Cazes, Sandrine and Alena Nesporova. 2003. Tržišta rada u tranziciji: Ravnoteža između fleksibilnosti i sigurnosti. Geneva: International Labour Office.

Cifrić, Ivan et. al. 1990. Potrošnja i životni standard. Znanstvene osnove dugoročnog društveno-ekonomskog razvoja Hrvatske. Zagreb: Ekonomski institut and Institut za društvena istraživanja Sveučilišta u Zagrebu.

Černelić, Milana. 2006. Bunjevačke studije. Zagreb: Odsjek za etnologiju i kulturnu antropologiju - Filozofski fakultet, Sveučilište u Zagrebu and FF press.

Černelić, Milana and Tihana Rubić. "Characteristic features of the zadruga of the Croatian subethnic group of Bunjevci". The History of the Family (forthcoming).

Čulinović-Konstantinović, Vesna. 1984. “Običajno pravo, njegova primjena i proučavanje do polovine 20. stoljeća”. Etnološka tribina 6-7: 51-70.

Dunn, Elizabeth C. 2004. Privatizing Poland. Baby Food, Big Business and the Remaking of Labor. Ithaca and New York: Cornell University Press.

Galić, Zvonimir. 2008. Nezaposlenost, traženje posla i zapošljavanje: longitudinalna analiza psiholoških aspekata. Unpublished Ph. D. thesis. Zagreb: University of Zagreb.

Guardiancich, Igor. 2007. "Politička ekonomija mirovinskih reformi u Hrvatskoj 1991. 2006". Financijska teorija i praksa 31/2: 89-150.

Gulin Zrnić, Valentina. 2009. Kvartovska spika. Značenje grada i urbani lokalizmi u Novom Zagrebu. Zagreb: Institut za etnologiju i folkloristiku and Naklada Jesenski i Turk.

Hart, Keith. 1973. "Informal Income Opportunities and Urban Unemployment in Ghana". The Journal of Modern African Studies 11/1: 67-89.

Haviland, William. 2004. Kulturna antropologija. Jastrebarsko: Naklada Slap.

Heady, Patrick and Pieter Schweitzer, eds. 2010. Family, Kinship and State in Contemporary Europe. The View from Bellow: Nineteen localities, Vol. 2. Frankfurt and New York: Campus Verlag. 
Hutinec, Boris, ed. 1971. Zagreb u 1971. Zagreb: Skupština Grada Zagreba.

Janković, Josip, Gordana Berc and Slavica Blažeka. 2004. "Neke opće i obiteljske vrednote u selu i u gradu". Sociologija sela 42: 91-111.

Karajić, Nenad. 2002. "Siromaštvo i neslužbeno gospodarstvo u Hrvatskoj - kvalitativni aspekti". Financijska teorija i praksa 26: 273-299.

Kaser, Karl. 2012. Households and Family in the Balkans. Two Decades of Historical Family Research at University of Graz. Berlin: LIT.

Kerovec, Nada. 2001. "Poteškoće u zapošljavanju osoba starije dobi”. Revija za socijalnu politiku 8: 267-277.

Kremenšek, Slavko. 1970. Ljubljansko naselje Zelena Jama kot etnološki problem. Ljubljana: SAZU.

Lee, Gary R. 1980. "Kinship in the Seventies: A Decade Review of Research and Theory". Journal of Marriage and Family 42/4: 923-934.

Leutloff-Grandits, Carolin, Danijela Birt and Tihana Rubić. 2012. "Two Croatian Localities (2010)". In Households and Family in the Balkans. Two Decades of Historical Family Research at University of Graz. Karl Kaser ed. Berlin: LIT, 587-615.

Macura, Miloš, ed. 1965. Jugoslavija 1945 - 1964.: statistički pregled. Beograd: Savezni zavod za statistiku.

Macura, Sanja. 2005. Psihološki učinci rada "na crno". Unpublished diploma thesis. Zagreb: University of Zagreb.

Malenica, Zoran. 2007. Ogledi o hrvatskom društvu. Lice i naličje hrvatskog društva. Zagreb: Golden marketing and Tehnička knjiga.

Milić, Anđelka. 2007. Sociologija porodice. Beograd: Čigoj štampa.

Milovanović, Mihajlo, ed. 1986. Jugoslavija 1945 - 1985: statistički prikaz. Beograd: Savezni zavod za statistiku.

Mucko, Bojan. 2009. "Podaj majko - semiotička analiza podgorskog identiteta”. Senjski zbornik 36: 275-299.

Muraj, Aleksandra. 1990. “Alternativno trgovanje između potrebe i razonode”. Etnološka tribina 13: 33-40.

Muraj, Aleksandra. 2002. "Ekonomska djelatnost srijemskih Hrvata (stanje iz godine 1996.)”. In Srijemski Hrvati. Etnološka studija migracije, identifikacije i interakcije. Jasna Čapo Žmegač. Zagreb: Durieux, 269-297.

Ott, Katarina. 2002. "Neslužbeno gospodarstvo u Republici Hrvatskoj 1990. - 2000." Financijska teorija i praksa 26/1: 1-30.

Podgorelec, Sonja and Sanja Klempić. 2007. "Starenje i neformalna skrb o starim osobama u Hrvatskoj”. Migracijske i etničke teme 23: 111-134.

Puljiz, Vlado. 1977. Eksodus poljoprivrednika. Zagreb: Centar za sociologiju sela, grada i prostora Instituta za društvena istraživanja Sveučilišta u Zagrebu.

Radonjić, Branka. 2001. "Tranzicija stambenog sektora i uspostava stambenog tržišta". Građevinar 53/6: 387-393.

Rihtman-Auguštin, Dunja. 1984. Struktura tradicijskog mišljenja. Zagreb: Školska knjiga. 
Rihtman-Auguštin, Dunja. 1996. "Junaci i klijenti. Skica za istraživanje mentaliteta”. Erasmus 16: 54-61.

Rubić, Tihana. 2008. “Tradicijska trgovina i sajmovi”. In Živjeti na Krivom Putu: Etnološkopovijesna monografija o primorskim Bunjevcima, Vol. 1. Milana Černelić, Marijeta Rajković and Tihana Rubić eds. Zagreb: Odsjek za etnologiju i kulturnu antropologiju, Gradski muzej Senj and FF-press, 323-352.

Rubić, Tihana and Danijela Birt. 2009. “Obiteljski život, odnosi i vrijednosti”. In Živjeti na Krivom Putu: Etnološka monografija o primorskim Bunjevcima, Vol. 2. Milana Černelić, Marijeta Rajković and Tihana Rubić eds. Zagreb: Odsjek za etnologiju i kulturnu antropologiju, Gradski muzej Senj and FF-press, 31-56.

Rubić, Tihana and Petra Petrak. 2010. "Normalno da će on pomoć". Obiteljski život i međugeneracijska uzajamna pomoć u lovinačkom kraju”. Senjski zbornik 37: 227-259.

Rubić, Tihana and Carolin Leutloff-Grandits. “Creating a Familiar Space: Childcare, Kinship and Community in Post-socialist New Zagreb". In Narrating the City. Wladimir Fischer and Anastasia Christou, eds. (forthcoming).

Sampson, Steven. 2002. "Beyond transition: rethinking elite configurations in the Balkans". In Postsocialism: Ideals, Ideologies and Practices in Eurasia, Chris M. Hann, ed. London and New York: Routledge, 31-56.

Seferagić, Dušica. 1988. Kvaliteta života i nova stambena naselja. Zagreb: Sociološko društvo Hrvatske.

Segalen, Martine. 1984. "Nuclear is Not Independent". In Households: Comparative and Historical Studies of the Domestic Group. Robert Netting, Richard Wilk and Eric J. Arnould, eds. Berkeley, Los Angeles and London: University of California Press, 163-186.

Supek, Olga. 1989. "Peasant versus Capitalist Worldview in Vinogorje of the 1930's", Etnološki pregled 25: 61-80.

Šakić, Vlado. 1999. "Socijalna pravednost i privatizacija u Hrvatskoj: sociopsihološki pogled". In Privatizacija i javnost. Drago Čengić and Ivan Rogić, eds. Zagreb: Institut društvenih znanosti Ivo Pilar.

Šantek, Goran Pavel. 2000. Cresko ribarstvo. Prilog ekonomskoj antropologiji. Unpublished MA thesis. Zagreb: University of Zagreb.

Sekelj, Laslo. 1990. Jugoslavija: struktura raspadanja. Beograd: Rad.

Štulhofer, Aleksandar. 2000. Nevidljiva ruka tranzicije. Zagreb: Hrvatsko sociološko društvo.

Šundalić, Antun. 2001. "Sustav vrijednosti u vrijeme politike zaborava". In Globalizacija $i$ njene refleksije u Hrvatskoj. Matko Meštrović, ed. Zagreb: Ekonomski institut, 65-82.

Teodorović, Ivan. 2001. "Tranzicijski proces u globalnoj okolini”. In Globalizacija i njene refleksije u Hrvatskoj. Matko Meštrović, ed. Zagreb: Ekonomski institut, 133-148.

Vojnić, Dragomir. 1996. "Ekonomska politika u tranziciji”. Ekonomija 2/1: 177-193.

Woodward, Susan L. 1995. Socialist Unemployment. The Political Economy of Yugoslavia 1945 - 1990. Princeton: Princeton University Press.

Županov, Josip. 1995. Poslije potopa. Zagreb: Globus. 